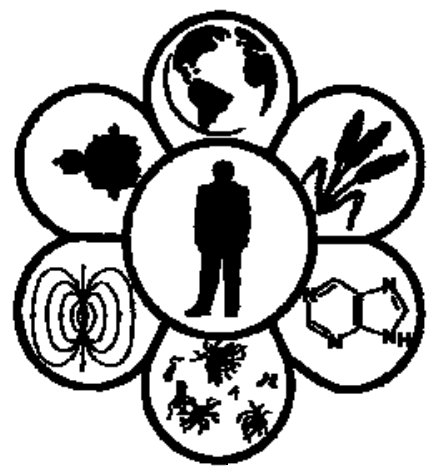

Вісник Дніпропетровського університету. Біологія, медицина Vìsnik Dnìpropetrovs'kogo unìversitetu. Seriâ Bìologiâ, medicina Visnyk of Dnipropetrovsk University. Biology, medicine

Vìsn. Dnìpropetr. Unìv. Ser. Bìol. Med. 2014. 5(1), 12-16. doi:10.15421/021403

ISSN 2310-4155 print ISSN 2312-7295 online www.medicine.dp.ua

\title{
УДК 577.125:591.436 \\ Інтенсивність окисних процесів у мікросомній фракції печінки щурів за умов різного забезпечення поліненасиченими жирними кислотами
}

\author{
О.В. Кеца, М.В. Зазулик, М.В. Хімчак \\ Чернівещький національний університет імені Юрія Федьковича, Чернівиі, Україна
}

Досліджено вплив жирових композицій раціону з різним умістом поліненасичених жирних кислот (ПНжК) родин $\omega-6$ i $\omega-3$ на інтенсивність окисних процесів у мікросомній фракції печінки щурів. Чотиритижневе додавання до раціону тварин лише $\omega-6$ ПНЖК зумовлює підвищення пероксидного окислення ліпідів і окислювальної модифікації протеїнів у мікросомній фракції печінки щурів порівняно з контрольною групою тварин. Використання високих доз $\omega$-3 ПНЖК (ейкозапентаєнової (ЕРА) та докозагексаєнової кислот (DHA)) не впливає на інтенсивність вільнорадикального окислення ліпідів і протеїнів. Відсутність у раціоні тварин ПНЖК сприяє підвищенню інтенсивності вільнорадикальних процесів у мікросомній фракції печінки щурів.

Ключові слова: поліненасичені жирні кислоти; ліпопероксидація; окислювальна модифікація білків; мікросомна фракція; печінка

\section{Oxidation process intensity in microsomal fraction of rat liver under conditions of different supplementation with polyunsaturated fatty acids}

\author{
O.V. Ketsa, M.V. Zazulyk, M.V. Himchak \\ Yuri Fedkovich Chernivtsy National University, Chernivtsy, Ukraine
}

\begin{abstract}
The effect of fat compositions with the varying ratio of polyunsaturated fatty acids (PUFAs) of families $\omega-3$ and $\omega-6$ on oxidation process intensity in microsomal fraction of rat liver has been investigated. The aim of the study was to investigate the level of markers of oxidative modification of lipids and proteins in microsomal fraction of rat liver. Fat components in the experiment diets were presented by sunflower oil, soybean oil and fish oil. Rats were fed using one of the fillowing 5 diets for the period of 4 weeks: 1) AIN-93 diet with 7\% sunflower oil and fish oil, with the inclusion of linoleic acid, eicosapentaenoic acid and docosahexaenoic acid in the ratio of $\omega-6: \omega-3-7: 1$ (control diet); 2) AIN-93 diet with 7\% soybean oil, with the inclusion of linoleic acid and $\alpha$-linolenic acid in the ratio of 7:1;3) the diet containing only $\omega-6$ PUFAs; 4 ) the diet containing only $\omega$-3 PUFAs; 5 ) the diet without PUFAs. The fatty acid compositions of the diets were analysed by gas chromatography. We measured the primary and secondary lipoperoxidation products, proteins carbonyl derivatives and $\mathrm{SH}$-groups of proteins. It was shown that inclusion of linoleic acid and $\alpha$-linolenic acid in the ratio of 7:1 or $\omega-6$ PUFAs into the animal diet increased lipid peroxidation in microsomal fraction of the rat liver as compared with the control group. Only $\omega-6$ PUFAs increased the oxidative modification of proteins in microsomal fraction of the rat liver as compared with the control rat group. High dose of $\omega-3$ PUFAs - eicosapentaenoic acid and docosahexaenoic acid had no influence on free radical oxidation of lipids and proteins. Using the diet without PUFAs increased oxidation process intensity in microsomal fraction of rat liver. According to our study, $\omega-6$ PUFAs increased the oxidative modification of lipids and proteins in microsomal fraction of the rat liver. $\omega$-3 PUFAs, in particular, eicosapentaenoic acid and docosahexaenoic acid, increased lipid and protein resistance to oxidative modification in microsomal fraction of the rat liver.
\end{abstract}

Keywords: fatty acids; lipoperoxidation; oxidative modification of proteins; microsomal fraction; liver

Чернівецький національний університет імені Юрія Федьковича, вул. Коиюбинського, 2, Чернівиі, 58012, Україна Yuri Fedkovich Chernivtsy National University, vul. Kotsyubinskogo, 2, Chernivtsy, 58012, Ukraine

Tel.+38-097-857-75-94.E-mail:ksen808@mail.ru 


\section{Вступ}

Поліненасичені жирні кислоти (ПНЖК) в організмі відіграють важливу роль у реалізації численних фізіологічних і біохімічних процесів. Організм використовує властивості ненасичених зв'язків під час синтезу важливих регуляторних сполук, що робить ПНЖК незамінними компонентами їжі (Jump et al., 2012; Roberts and Milne, 2009; Lawson et al., 2006). Серед ПНЖК треба

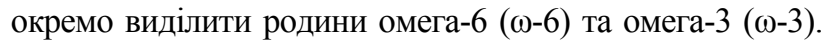
Біологічно активні речовини, що утворюються при метаболізмі $\omega-6$ і $\omega-3$ ПНЖК, відіграють важливу роль у фізіологічних процесах організму, проте нерідко володіють протилежними властивостями (Simopoulos, 2008; Gillies et al., 2012). Враховуючи, що харчові джерела $\omega-3$ ПНЖК досить обмежені, а співвідношення $\omega-6 / \omega-3$ ПНЖК у раціоні людини складає 20:1, порівняно 3 рекомендованим від 7:1 до 1:1 (Simopoulos, 2006; Wertz, 2009), необхідно збагачувати раціон $\omega-3$ ПНЖК. Невивченими залишаються питання впливу різних доз і видів ПНЖК на організм, а також термін їх уживання та уникнення небажаних наслідків.

ПНЖК в організмі у першу чергу піддаються атаці активними формами оксигену, що викликає утворення різноманітних первинних i вторинних продуктів, які виконують важливі фізіологічні функції в організмі: активують процеси проліферації та диференціації клітин, беруть участь у регуляції проникливості клітинних мембран, транспорті іонів, підтриманні гомеостазу, формуванні резистентності організму (Chernyavsky et al., 2006; Guillou et al., 2010; Liu et al., 2013). Проте надлишкова інтенсифікація ланцюгових вільнорадикальних реакцій пероксидного окислення ліпідів (ПОЛ) супроводжується вивільненням жирних кислот, збільшенням проникливості мембран, загибеллю органел і клітин (Tanito et al., 2009; Bazan et al., 2011; Wu et al., 2011).

Процеси метаболізму ПНЖК в організмі значною мірою залежать від ензиматичних систем, локалізованих в ендоплазматичному ретикулумі (ЕПР) (Bryzgina et al., 2001; Yumino et al., 2002). ПНЖК, що входять до складу фосфоліпідів, є основою ліпідного матриксу біомембран i зумовлюють структурно-функціональні властивості протеїнових компонентів мембран внутрішньоклітинних органел (Hardman et al., 2002; Simopoulos, 2006). Зміни жирнокислотного складу мембран можуть впливати на конформацію протеїнів i, як наслідок, на їх функціональні властивості. 3 іншого боку, введення в організм різних видів ПНЖК може бути ланкою вільнорадикальних процесів, які виражатимуться в ініціації окислювальної модифікації протеїнів (Mitic-Oka et al., 2001; Feillet-Coudray et al., 2013; Lee et al., 2013). Сьогодні залишаються недостатньо вивченими характер та механізми змін структурних компонентів мембран ЕПР за умов диференційного застосування $\omega-6$ і $\omega-3$ ПНЖК.

Мета роботи - 3'ясувати інтенсивність вільнорадикального окислення ліпідів і протеїнів у мікросомній фракції печінки щурів за умов різної забезпеченості $\omega-6$ та $\omega-3$ поліненасиченими жирними кислотами.

\section{Матеріал і методи досліджень}

Дослідження проводили на білих безпородних щурах масою 90-110 г, які протягом 4 тижнів перебували на напівсинтетичному раціоні віварію, складеному на основі дієти AIN-93 (Reeves et al., 1993).

Тварин поділено на такі групи: I - щури, які отримували $\omega-6$ і $\omega-3$ ПНЖК у співвідношенні 7:1 (контроль). При цьому джерелом лінолевої кислоти (LA) слугувала соняшникова олія, а ейкозапентаєнової (ЕРА) та докозагексаєнової (DHA) - риб'ячий жир; II - тварини, до раціону яких додавали соєву олію, що містила LA i $\alpha$ ліноленову кислоту ( $\alpha$-LNA) у співвідношенні 7:1 (Reeves et al., 1993); III - тварини, які отримували лише $\omega-6$ ПНЖК; IV - щури, які отримували високі дози $\omega-3$ ПНЖК (EPA - 600 і DHA - 400 мг/кг маси тварин на добу); V - тварини, які перебували на раціоні, позбавленому ПНЖК.

Евтаназію тварин здійснювали під легким ефірним наркозом на 28-му добу з початку дієти. Виділення микросомної фракції проводили методом диференційного центрифугування. Інтенсивність процесів ПОЛ у мікросомній фракції печінки оцінювали за визначенням первинних (кетодієнів і спряжених трієнів) i вторинних (ТБК-активних) продуктів за методикою (Volchegorsky et al., 1989) та (Gavrilov et al., 1987), відповідно. Вміст первинних продуктів ПОЛ виражали у $\mathrm{E}_{278} / \mathrm{M \Gamma}$ білка. Визначення вмісту ТБК-активних продуктів у мікросомній фракції проводили за розрахунком вмісту основного складового - малонового альдегіду (МА) та виражали в ммоль/мг білка.

Процеси окислювальної модифікації протеїнів досліджували за визначенням вмісту карбонільних похідних і вільних $S H$-груп. Вміст карбонільних похідних у суспензіï мікросом визначали за методикою (Zaytseva and Shardenko, 2012). Визначення кількості вільних $S H$-груп протеїнів мікросом проводили методом, заснованим на їх взаємодії з 5,5'-дитіобіс-2-нітробензойною кислотою. Інтенсивність забарвлення реєстрували спектрофотометрично при 412 нм (Murphy and Kehrer, 1989). Вміст карбонільних похідних і вільних протеїнових $S H$-груп виражали в нмоль/мг білка. Порівняння вибірок проводили 3 використанням $t$-критерію Стьюдента, достовірними вважали відмінності при $P<0,05$.

\section{Результати та їх обговорення}

У мікросомній фракції печінки щурів, до раціону яких протягом 4 тижнів додавали LA: $\alpha$-LNA вміст кетодієнів і спряжених трієнів (рис. 1) та ТБК-активних продуктів (рис. 2) збільшувався в 1,4 та 1,3 раза, відповідно, порівняно з контрольною групою тварин, які поряд з LA отримували EPA і DHA ПНЖК.

Інтенсифікація процесів ліпопероксидації в мікросомній фракції печінки щурів за умов застосування  цілісності мембран ЕПР та зміну функціонування компонентів електронтранспортного ланцюга мікросом, наслідком чого може бути посилення генерації активних форм оксигену компонентами монооксигеназної системи (Marchenko and Ketsa, 2012). У нормі $\alpha$-LNA шляхом 
подовження та десатурації перетворюється на ЕРА i DHA, a LA - на арахідонову кислоту. Одночасне введення LA та $\alpha$-LNA може викликати конкуренцію цих ПНЖК за ензиматичні системи їх метаболізму, зокрема за $\Delta-6$ десатуразу, яка бере участь в утворенні подвійних зв'язків у молекулі жирної кислоти (Guillou et al., 2010; Serhiyenko et al., 2011). Отже, одночасне застосування LA i $\alpha$-LNA викликає підвищення процесів ліпопероксидації в мікросомній фракції печінки, а заміна в дієті $\alpha$-LNA на EPA і DHA зумовлює нормальний перебіг протікання процесів ПОЛ.

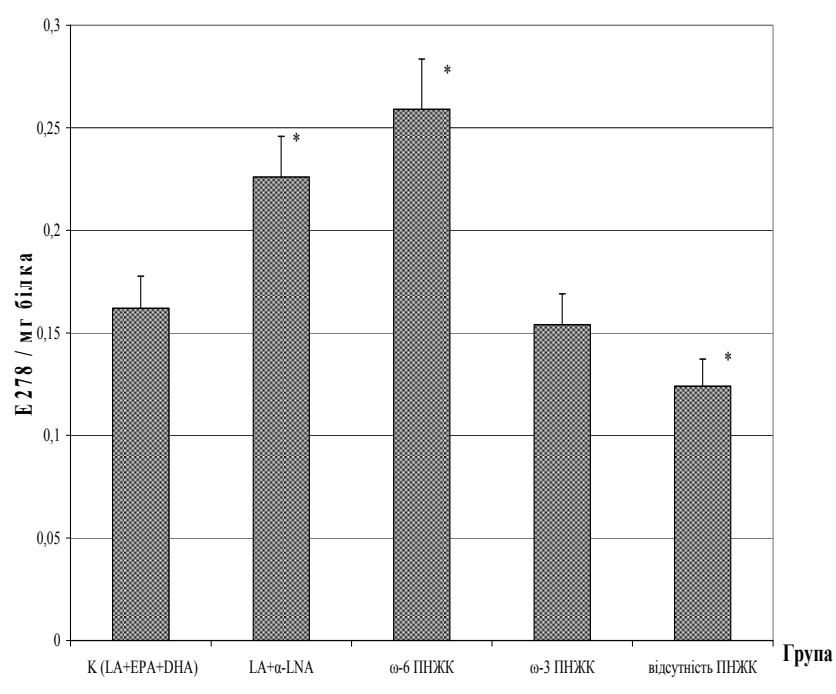

Рис. 1. Вміст кетодіснів і спряжених тріснів у мікросомній фракції печінки щурів за умов різного забезпечення поліненасиченими жирними кислотами:

K (LA+EPA+DHA) - контрольна група тварин, які отримували лінолеву, ейкозапентаєнову та докозагексаєнову кислоти; LA $+\alpha-\mathrm{LNA}$ - щури, які отримували лінолеву та $\alpha$-ліноленову кислоти; $\omega-6$ ПНЖК - щури, які отримували лише $\omega-6$ ПНЖК; $\omega-3$ ПНЖК - щури, які отримували високі дози $\omega-3$ ПНЖК; * - статистично достовірна різниця порівняно 3 контрольними показниками $(P<0,05)$

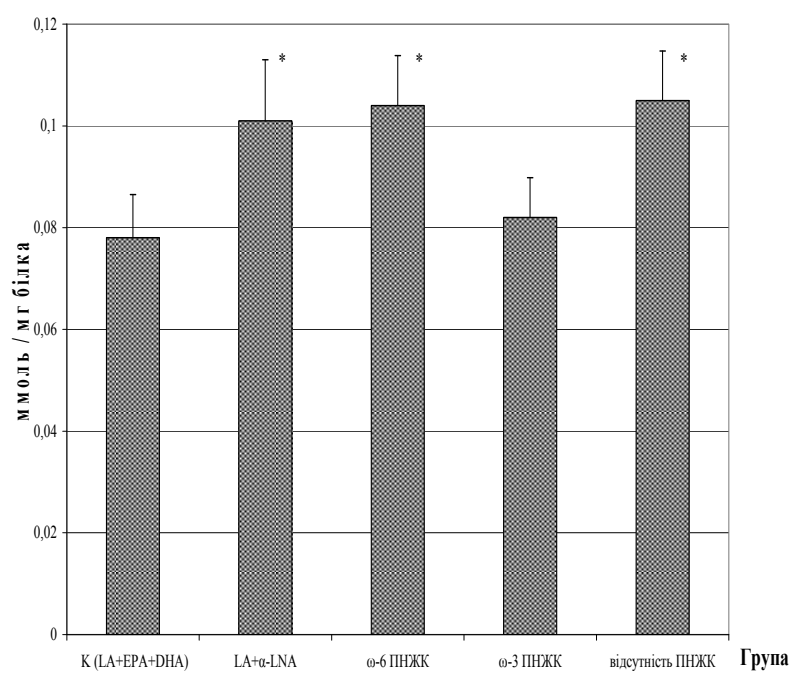

Рис. 2. Вміст ТБК-активних продуктів у мікросомній фракції печінки щурів за умов різного забезпечення поліненасиченими жирними кислотами: назви груп див. рис. 1
Аналіз даних групи тварин, до раціону яких додавали тільки $\omega-6$ ПНЖК, показав посилення процесів ліпопероксидації у мікросомній фракції печінки. Вміст кетодієнів і спряжених трієнів підвищувався у 1,6 раза (рис. 1), а ТБКактивних продуктів - у 1,4 раза (рис. 2) порівняно з показниками, характерними для контрольної групи тварин. Утримання щурів на раціоні, збагаченому $\omega-3$ ПНЖК (зокрема EPA і DHA), не викликає змін вмісту первинних i вторинних продуктів ПОЛ у мікросомній фракції печінки щурів порівняно з контролем (див. рис. 1 і 2).

Імовірно, збагачення раціону щурів $\omega-3$ ПНЖК зумовлює модифікацію жирнокислотного складу фосфоліпідів клітинних мембран у бік збільшення в них ПНЖК із родини $\omega-3$ та зменшення $\omega-6$ ПНЖК, що сприяє підвищенню стійкості до окислення через пригнічення вільнорадикальних процесів і посилення ферментативної ланки антиоксидантного захисту (Kukoba et al., 2005). Наслідком такої зміни у жирнокислотному складі фосфоліпідів може бути стабілізація мембран ЕПР.

Отже, збагачення дієти $\omega-6$ ПНЖК викликає збільшення вмісту первинних та вторинних продуктів ПОЛ, тоді як $\omega-3$ ПНЖК тваринного походження проявляють антиоксидантний ефект у мікросомній фракції печінки, стабілізуючи процеси ПОЛ.

У групи щурів, які протягом 4 тижнів не отримували взагалі ПНЖК, вміст кетодієнів і спряжених трієнів у мікросомній фракції печінки зменшувався в 1,3 раза, а ТБК-активних продуктів підвищувався у 1,4 раза порівняно з контрольною групою. Одна із причин зниження первинних продуктів ПОЛ - дефіцит субстрату для процесів ліпопероксидації. Водночас, підвищення ТБК-активних продуктів може бути наслідком окислення жирних кислот, що входять до складу мембран, які відразу ж перетворюються на вторинні продукти (Murthy et al., 2002).

Вільнорадикальне окислення ліпідів мембран ЕПР може викликати окислювальну модифікацію мембранних протеїнів і ензимів, оскільки саме фосфоліпіди стабілізують їх у структурно-функціональній конформації. ПОЛ, як модифікатор мікросомних фосфоліпідів, може виступати в ролі фактора, який викликає зміни конформації мембран, і регулювати тим самим активність ряду мембранозв'язаних ензимів мікросом (Marchenko and Ketsa, 2012).

Результати проведених досліджень показали, що вживання $\omega-3$ ПНЖК рослинного походження - $\alpha$-LA поряд із введенням LA ( $\omega-6)$ не спричинює зміни вмісту карбонільних похідних (рис. 3) і сульфгідрильних груп (рис. 4) протеїнів у мікросомній фракції печінки щурів порівняно з показниками контрольної групи. Імовірно, процеси окислювальної модифікації протеїнів у мікросомній фракції печінки щурів не залежать від виду $\omega-3$ ПНЖК в умовах чотиритижневого введення в організм комплексу $\omega-6 / \omega-3$ ПНЖК у співвідношенні 7:1. 3 іншого боку, до 15\% $\alpha$-LA, що потрапляє до організму, може перетворитися на EPA і DHA (Simopoulos, 2006; Guillou et al., 2010), що можливо і $є$ причиною однакового ефекту досліджуваних $\omega-3$ ПНЖК на процеси окислювальної модифікації протеїнів.

Аналіз результатів досліджень групи тварин, які отримували лише $\omega-6$ ПНЖК, показав підвищення вмісту протеїнових карбонільних похідних в 1,4 раза (рис. 3) 
i зниження рівня сульфгідрильних груп протеїнів в 1,7 раза (рис. 4) в мікросомній фракції печінки щурів порівняно з показниками, характерними для контрольної групи. Імовірно, ініціація вільнорадикальних процесів в організмі відбувається під час окислення $\omega-6$ ПНЖК у реакціях, які каталізуються циклооксигеназами, ліпоксигеназами та цитохромом $\mathrm{P}_{450}$. Субстратом для цих ензимів $є$ неестерифікована арахідонова кислота, під час ензиматичного окислення якої утворюються пероксидні та вільнорадикальні ейкозаноїди, що генерують активні форми оксигену (Roberts and Milne, 2009; Wertz, 2009).

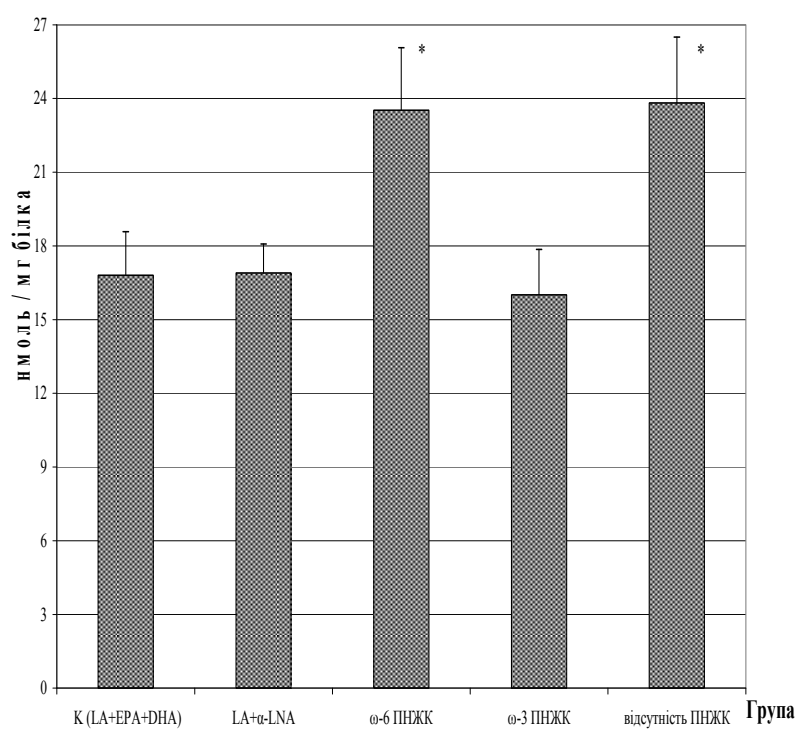

Рис. 3. Вміст карбонільних похідних протеїнів мікросомної фракції печінки щурів за умов різного забезпечення поліненасиченими жирними кислотами

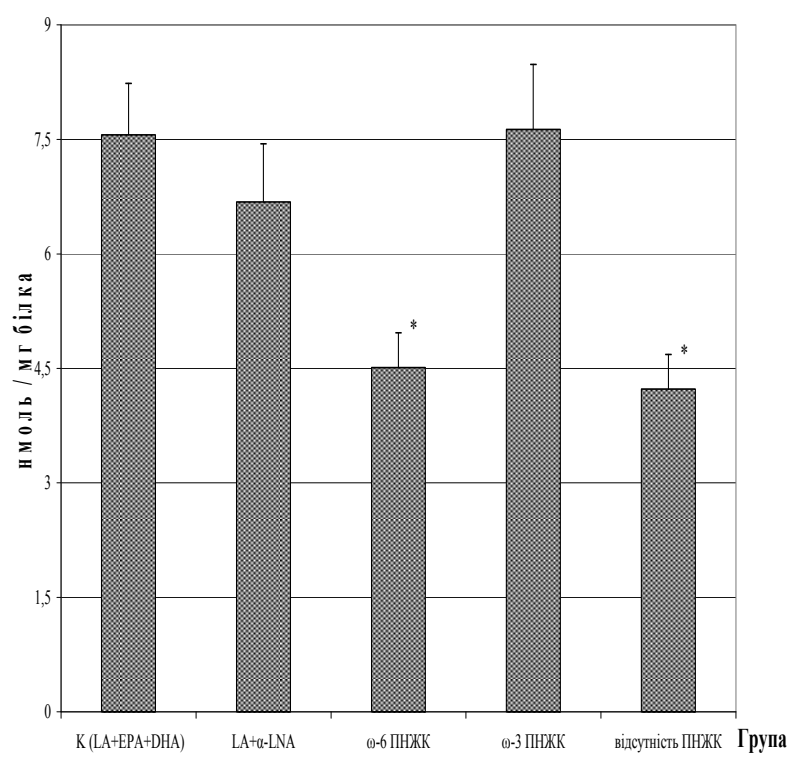

Рис. 4. Вміст сульфгідрильних груп протеїнів мікросомної фракції печінки щурів за умов різного забезпечення поліненасиченими жирними кислотами

Окислення протеїнів мікросомної фракції печінки може викликати інактивацію цитохрому $\mathrm{P}_{450}-$ ензиму, що бере участь не лише в біотрансформації ксенобіотиків, а й у метаболізмі ПНЖК. Відхилення в роботі монооксигена- зної системи може зумовити додаткову генерацію активних форм оксигену (Marchenko and Ketsa, 2012).

Чотиритижневе додавання до раціону препаратів, збагачених $\omega$-3 ПНЖК, не викликає змін вмісту карбонільних похідних і SH-груп протеїнів мікросомної фракції печінки порівняно 3 показниками контрольної групи щурів (див. рис. 3 та 4). Стабілізація окислювальної модифікації протеїнів за дії $\omega-3$ ПНЖК може бути наслідком стабілізації мембран ЕПР та пригнічення утворення вільних радикалів клітинними генераторами (Kukoba et al., 2005).

Повна відсутність у раціоні щурів ПНЖК викликає підвищення в 1,4 раза протеїнових карбонільних похідних (див. рис. 3) і зниження в 1,8 раза сульфгідрильних груп протеїнів (див. рис. 4) у мікросомній фракції печінки щурів порівняно з показниками контрольної групи тварин на 28-му добу експерименту. Імовірно, нестача в раціоні ПНЖК зумовлює дестабілізацію та дисфункцію мембран ЕПР не тільки за рахунок зміни жирнокислотного складу мембран, а i за рахунок зміни їх фізикохімічних властивостей - мікров'язкості, текучості, мембранного потенціалу. Вказані зміни мембран викличуть інтенсифікацію окислення протеїнів, а це, у свою чергу, - зміну активностей мембранозв'язаних ензимів (Marchenko and Ketsa, 2012).

\section{Висновки}

 окислення ліпідів і протеїнів мікросомної фракції печінки щурів, що виражається у підвищенні рівня первинних і вторинних продуктів ПОЛ, протеїнових карбонільних похідних і зниженні вмісту $S H$-груп протеїнів. Збагачення раціону щурів $\omega-3$ ПНЖК підвищує стійкість ліпідів і мембранозв'язаних протеїнів мікросомної фракції печінки щурів до вільнорадикального окислення.

\section{Бібліографічні посилання}

Bazan, N.G., Musto, A.E., Knott, E.J., 2011. Endogenous signaling by omega-3 docosahexaenoic acid-derived mediators sustains homeostatic synaptic and circuitry integrity. Mol. Neurobiol. 44, 216-222.

Bryzgina, T.M., Aleksyuk, L.I., Martinova, T.V., Sukhina, V.S., Alexeyeva, I.N., 2001. Vplyv blokatoriv cyklooksygenaznogo ta lipooksygenaznogo shljahiv metabolizmu arahidonovoi' kysloty na imunnu vidpovid', aktyvnist' monooksygenaznoi' systemy i perekysnogo okyslennja lipidiv u selezinci ta pechinci myshej [The effects of inhibitors of cyclooxygenase and lypoxygenase pathways of oxidation of arachidonic acid on the immune response, and the activity of monooxygenase system and lipid peroxidation in mice]. Physiol. J. 47, 46-52 (in Ukrainian).

Chernyavsky, P.V., Datsenko, Z.M., Moiseyeva, L.G., Kanivets, N.V., Kozulina, O.P., Boroda, A.M., Abakumova, O.S., 2006. Reguljacija vnutrishn'oklitynnogo obminu lipidiv preparatom $\omega$-3-fosfolipidiv iz mors'kyh organizmiv pry deficyti esencijnyh zhyrnyh kyslot $\mathrm{u}$ shhuriv [Regulation of intracellular lipid metabolism by the preparation of $\omega-3$ phospholipids from marine organisms under deficit of essential fatty acid in rats]. Ukr. Biochem. J. 78, 101-114 (in Ukrainian).

Feillet-Coudray, C., Aoun, M., Fouret, G., Bonafos, B., Ramos, J., Casas, F., Cristol, J.P., Coudray, C., 2013. Effects of 
long-term administration of saturated and n-3 fatty acid-rich diets on lipid utilization and oxidative stress in rat liver and muscle tissues. Br. J. Nutr. 110(10), 1789-1802.

Gavrilov, V.B., Gavrilova, A.R., Mazhul, L.M., 1987. Analyz metodov opredelenyja produktov perekysnogo okyslenyja lypydov v syvorotke krovi po testu s tyobarbyturovoj kyslotoj [Analysis of the procedures for estimation of lipid peroxidation products using thiobarbituric acid test]. Quest. Med. Chem. 33, 118-122 (in Russian).

Gillies, P.J., Bhatia, S.K., Belcher, L.A., Hannon, D.B., Thompson, J.T., Heuvel, J.P.V., 2012. Regulation of inflammatory and lipid metabolism genes by eicosapentaenoic acid-rich oil. J. Lipid Res. 53, 1679-1689.

Guillou, H., Zadravec, D., Martin, P.G., Jacobsson, A., 2010. The key roles of elongases and desaturases in mammalian fatty acid metabolism: Insights from transgenic mice. Prog. Lipid Res. 49, 186-199.

Hardman, W.E., Munoz, J. Jr, Cameron, I.L., 2002. Role of lipid peroxidation and antioxidant enzymes in omega- 3 fatty acids induced suppression of breast cancer xenograft growth in mice. Cancer Cell Int. 2, 10-19.

Jump, D.B., Depner, C.M., Tripathy, S., 2012. Omega-3 fatty acid supplementation and cardiovascular disease. J. Lipid Res. 53, 2525-2545.

Kukoba, T., Shysh, A., Moibenko, A.A., Kotsjuruba, A., Kharchenko, O., 2005. Vplyv $\omega-3$ polinenasychenyh zhyrnyh kyslot na perekysne okyslennja lipidiv [The effects of omega-3 polyunsaturated fatty acids on lipid peroxidation]. Physiol. J. 51, 26-32 (in Ukrainian).

Lawson, J.A.., Kim, S., Powell, W.S., FitzGerald, G.A., Rokach, J., 2006. Oxidized derivatives of $\omega-3$ fatty acids: Identification of IPF3 $\alpha$-VI in human urine. J. Lipid Res. 47, 2515-2524.

Lee, L.K., Shahar, S., Rajab, N., Yusoff, N.A.M., Jamal, R.A., Then, S.M., 2013. The role of long chain omega-3 polyusaturated fatty acids in reducing lipid peroxidation among elderly patients with mild cognitive impairment: A case-control study. J. Nutr. Biochem. 24, 803-808.

Liu, X., Xue, Y., Liu, C., Lou, Q., Wang, J., Yanagita, T., Xue, C., Wang, Y., 2013. Eicosapentaenoic acid-enriched phospholipid ameliorates insulin resistance and lipid metabolism in diet-induced-obese mice. Lipids Health Dis. 12, 109-119.

Marchenko, M.M., Ketsa, O.V., 2012. Functional activity of the NADH-dependent reductase system in liver and Guerin's carcinoma microsomal fraction in rats exposed to preliminary irradiation. Biochem. (Mosc.) 6B, 321-327.

Marchenko, M.M., Ketsa, O.V., 2012. Generacija superoksydnogo radykala komponentamy monooksygenaznoi' systemy pechinky poperedn'o oprominenyh shhuriv-puhlynonosii'v [Generation of superoxide anion-radical in the liver monooxygenase system of preliminary radiation-exposed tumor-bearing rats]. Ukr. Biochem. J. 84, 95-102 (in Ukrainian).

Mitic-Oka, J., Simic, T., Pljesa, M., Stupar, N., Turkovic, S., 2001. Oxidative modification of plasma proteins in different stages of chronic renal failure. Med. Biol. 8, 1-5.
Murphy, M.E., Kehrer, J.P., 1989. Oxidation state of tissue thiol groups and content of protein carbonyl groups in chickens with inherited muscular dystrophy. Biochem. J. 260, 359-364.

Murthy, M., Hamilton, J., Greiner, R.S., Moriguchi, T., Salem, N., Kim, H.-Y., 2002. Differential effects of $\omega-3$ fatty acid deficiency on phospholipids molecular species composition in the rat hippocampus. J. Lipid Res. 43, 611-617.

Reeves, P.G., Nielsen, F.H., Fahey, G.C., 1993. AIN-93 purified diets for laboratory rodents: final report of the American Institute of Nutrition Ad Hoc writing committee on the reformulation of the AIN-76A rodent diet. J. Nutr. 123, 19391951.

Roberts, L.J., Milne, G.L., 2009. Isoprostanes. J. Lipid Res. 50, 219-223.

Serhiyenko, V.A., Serhiyenko, A.A., Efimov, A.S., 2011. Dovgolancjugovi $\omega-3$ polunenasycheni zhyrni kysloty: Sercevosudynni zahvorjuvannja i cukrovyj diabet [Long-chain $\omega-3$ polyunsaturated fatty acids: Cardiovascular diseases and type 2 diabetes mellitus]. J. NAMN Ukr. 17, 353-367 (in Ukrainian).

Simopoulos, A.P., 2006. Evolutionary aspects of diet, the omega-6/omega-3 ratio and genetic variation: Nutritional implications for chronic diseases. Biomed. Pharmacother. 60, 502-507.

Simopoulos, A.P., 2008. The importance of the omega-6/omega3 fatty acid ratio in cardiovascular disease and other chronic disease. Exp. Biol. Med. (Maywood) 233, 674-688.

Tanito, M., Brush, R.S., Elliott, M.H., Wicker, L.D., Henry, K.R., Anderson, R.E., 2009. High levels of retinal membrane docosahexaenoic acid increase susceptibility to stressinduced degeneration. J. Lipid Res. 53, 807-819.

Volchegorsky, I.A., Nalimov, A.G., Yarovinsky, B.G., Lifshitz, R.I., 1989. Sopostavlenie razlichnyh podhodov k opredeleniju produktov perekisnogo okislenija lipidov $\mathrm{V}$ geptanizopropanol'nyh jekstraktah krovi [Different means of lipid peroxidation products estimation in heptane-isopropanol extracts of blood]. Quest. Med. Chem. 35, 127-131 (in Russian).

Wertz, P.W., 2009. Essential fatty acids and dietary stress. Toxycol. Ind. Health. 25, 279-283.

Wu, J.H., Lemaitre, R.N., Imamura, F., King, I.B., Song, X., Spiegelman, D., Siscovick, D.S., Mozaffarian, D., 2011. Fatty acids in the de novo lipogenesis pathway and risk of coronary heart disease: The cardiovascular health study. Am. J. Clin. Nutr. 94, 431-438.

Yumino, K., Kawakami, I., Tamura, M., Hayashi, T., Nakamura, M., 2002. Paraquat- and diquat-induced oxygen radical generation and lipid peroxidation in rat brain microsomes. J. Biochem. 131, 565-570.

Zaytseva, O.V., Shardenko, S.G., 2012. Modyfikacija spektrofotometrychnogo metodu vyznachennja karbonil'nyh grup protei'niv. [Modification of spectrophotometric method of determination of protein carbonyl groups]. Ukr. Biochem. J. 84, 112-116 (in Ukrainian).

Надійшла до редколегї 18.02.2014 